\title{
Utilization of extracellular polymeric substances (EPS) immobilized in epoxy polymer as double ion exchanger biosorbent for removal of chromium from aqueous solution
}

\author{
Lilis Kistriyani ${ }^{\mathrm{a}}$, Zainus Salimin ${ }^{\mathrm{a}}$, Achmad Chafidz ${ }^{\mathrm{a}, \mathrm{b}^{*}}$ \\ ${ }^{a}$ Chemical Engineering Department, Universitas Islam Indonesia, Yogyakarta 55584, Indonesia \\ ${ }^{b}$ Center for Material Science and Technology Studies, Chemical Engineering Department, Universitas Islam Indonesia, Yogyakarta 55584, Indonesia
}

Received: 15 May 2020 / Received in revised form: 13 June 2020 / Accepted: 15 June 2020

\begin{abstract}
Extracellular Polymeric Substance (EPS) can be used as a biosorbent and ion exchange bioresin replacing organic resins. It is because EPS contains organic functional groups i.e. cation and anion absorbers. Additionally, epoxy resin also has a sorption capability for chromium ions. In this study, the EPS was immobilized in epoxy polymer to improve usability of the biosorbent. The objective of this research is to study the utilization of EPS immobilized in epoxy polymer as a double ion exchanger biosorbent to remove chromium ions from aqueous solution. The EPS was extracted from activated sludge bacterial by centrifugation at $9000 \mathrm{rpm}$ for 20 minutes at $4{ }^{\circ} \mathrm{C}$. The functional group analysis results with Fourier Transform Infra-Red (FT-IR) Spectroscopy showed that the EPS containing chemical bonds such as $-\mathrm{CH},-\mathrm{OH}$, $-\mathrm{NH}$, and $-\mathrm{C}=\mathrm{O}$ which proved that EPS were exchanging cations and anions. Additionally, the epoxy polymer was prepared by mixing bisphenol A monomers and epichlorohydrin at weight ratio of 1:1. The Immobilized EPS double ion exchange bioresin in epoxy polymers was prepared by mixing $200 \mathrm{mg}$ EPS and $1800 \mathrm{mg}$ epoxy at pH 5, 6 and 7. The analysis results showed that the optimum result gave the chromium ion absorption efficiency of $89.20 \%$ at $\mathrm{pH} 5$.
\end{abstract}

Keywords: Extracellular polymeric substance (EPS), activated sludge bacteria, epoxy polymer, biosorbent, chromium

\section{Introduction}

Several industries (such as electroplating, textile, metallurgy, mining, battery, or ceramic) release wastewater which contains heavy metals into environment, mostly aquatic ecosystem [1]. These heavy metals are difficult to be degraded and tend to accumulate and this is why they are considered as the persistent environmental pollutant [2]. They are also harmful to humans and animals due to their toxicity. Therefore, the presence of these heavy metals in the environment becomes a great concern of researchers in the world [3]. Heavy metals, such as chromium - if not treated using adequate treatment - might threat human health and environment. $\mathrm{Cr}(\mathrm{IV})$ is more toxic than $\mathrm{Cr}(\mathrm{III})$ due to its mobility [4].

There are many different methods for the removal of heavy metal ions from the aqueous solution, such as adsorption, evaporation, chemical precipitation, electrochemical treatment, ion exchange, and membrane technologies [5]. However, these methods disadvantageously are high energy consuming, needs high amount of reagent,

* Corresponding author.

Email: achmad.chafidz@uii.ac.id generates floc residues as secondary pollution, and has low removal efficiency when the concentration of heavy metal pollutants in the range of $1-100 \mathrm{mg} / \mathrm{L}$ [6]. Biosorption has been considered as a promising alternative method for the removal heavy metal pollutants due to its effectiveness and eco-friendly [7]. One type of biosorbent that has attracted interest among researchers is Extracellular polymeric substances (EPS), resulted from microorganisms, i.e. living and dead bacteria cells. The EPS contain a great amount of negatively charged functional groups, such as carboxyl ($\mathrm{COOH})$, or phosphate $\left(-\mathrm{OPO}_{3} \mathrm{H}\right)$, sulphate $\left(-\mathrm{OSO}_{3} \mathrm{H}\right)$ and the positively charged functional groups such as hydroxyl (-R$\mathrm{OH})$, and amino carboxylic $\left(\mathrm{R}-\mathrm{C}\left(\mathrm{NH}_{2}\right) \mathrm{H}-\mathrm{COOH}\right)$; hence, they can interact/react with heavy metals ions as ligands [6, 8, 9]. Based on the literatures, EPS has a significant potential for the removal of heavy metals from aqueous solution $[6,7,10]$.

The EPS mainly consists of polysaccharides (40-95\% of total EPS), protein (1-60\%), nucleic acid (1-10\%), lipids (1$10 \%)$, and other compounds like amino acid polymer and bacteria [9,11]. The EPS can be used as biosorbent that is capable of binding the cations and anions of environmental pollutant, e.g. heavy metals by the mechanism of ion exchange, complex formation, hydrogen bonding and absorption. The cations binding by EPS is done by the 
presence of functional groups, such as carboxyl, phosphate, and sulphate as the following reaction $[9,12]$ :

$$
\begin{aligned}
& \mathrm{n} \mathrm{R}-\mathrm{COOH}+\mathrm{M}^{\mathrm{n}+} \rightarrow(\mathrm{RCOO}) \mathrm{n} \mathrm{M}+\mathrm{n} \mathrm{H}^{+} \\
& \mathrm{n} \mathrm{R}-\mathrm{OPO}_{3} \mathrm{H}+\mathrm{M}^{\mathrm{n}+} \rightarrow\left(\mathrm{R}-\mathrm{OPO}_{3}\right) \mathrm{n} \mathrm{M}+\mathrm{n} \mathrm{H}^{+} \\
& \mathrm{n} \mathrm{R-OSO} \mathrm{H}^{\mathrm{n}}+\mathrm{M}^{\mathrm{n}+} \rightarrow\left(\mathrm{R}^{-} \mathrm{OSO}_{3}\right) \mathrm{n} \mathrm{M}+\mathrm{n} \mathrm{H}^{+}
\end{aligned}
$$

$\mathrm{Mn}^{+}$is the positively charged cation on the EPS that can be driven out by another cation with the greater selectivity. The greater selectivity is the preference for ion by the ion exchanger of functional group. An ion exchanger tends to prefer [13]:

(1) Ions with higher valence

(2) Ions with smaller solvated volume

(3) Ions with greater ability for polarization

(4) Ions with stronger reaction with the ion exchange sites of the ion exchanger solid, and

(5) Ions with least participation with other ions to form complexes

For the usual cation exchanger, the preference series for the most common cations are as follows $[13,14]$ :

$\mathrm{Ba}^{+2}>\mathrm{Pb}^{+2}>\mathrm{Sr}^{+2}>\mathrm{Ca}^{+2}>\mathrm{Ni}^{+2}>\mathrm{Cd}^{+2}>\mathrm{Cu}^{+2}>\mathrm{Co}^{+2}>\mathrm{Zn}^{+2}>$ $\mathrm{Mg}^{+2}>\mathrm{Ag}^{+1}>\mathrm{Cs}^{+1}>\mathrm{K}^{+1}>\mathrm{NH}^{+1}>\mathrm{Na}^{+1}>\mathrm{H}^{+1}$ and $\mathrm{UO}^{2+}>>$ $\mathrm{Cu}^{2+}>>\mathrm{Co}^{2+}$

The anions binding of anion by EPS is performed by the functional groups of hydroxyl and amino carboxylic $[9,12]$ :

$\mathrm{R}-\mathrm{OH}+\mathrm{CrO}_{4}{ }^{2-} \rightarrow \mathrm{R}_{2} \mathrm{CrO}_{4}+2 \mathrm{OH}^{-}$

$\mathrm{R}-\mathrm{CH}-\mathrm{COOH} \rightarrow \mathrm{R}-\mathrm{CH}-\mathrm{COO}$

$\mathrm{NH}_{2} \mathrm{NH}_{3}^{+}$

$\mathrm{R}-\mathrm{CH}-\mathrm{COOH}+\mathrm{Cs}^{+}+\mathrm{NO}_{3}^{-} \rightarrow \mathrm{R}-\mathrm{CH}-\mathrm{COO}^{-}$

$\mathrm{NH}_{2} \mathrm{NH}_{3}{ }^{+}$

The functional groups of amino carboxylic also can bind the cation as shown in Equation 6. Whereas, for the anion exchanger, the following are preference sequences for the most common anions $[13,14]$ :

$\mathrm{SO}_{4}^{-2}>\mathrm{I}^{-1}>\mathrm{NO}_{3}{ }^{-1}>\mathrm{CrO}_{4}{ }^{-2}>\mathrm{Br}^{-1}>\mathrm{Cl}^{-1}>\mathrm{OH}$.

The functional groups of amino carboxylic, hydroxyl, sulphate and phosphate also can bind the metal ion by complex formation. The complexion between organic ligands and metal ion may occur.

Several literatures have reported the utilization of EPS for the removal of heavy metals from wastewater. Nouha, et al. [15] studied about the heavy metals removal from industrial effluent using EPS produced by Cloacibacterium normanense in activated sludge with glycerol as the supplement. They also focused on EPS extraction by using different methods (i.e. centrifugation, heating, and EDTA). They reported that EPS production by Cloacibacterium normanense was influenced by different glycerol loadings in the medium. It was found that the EPS concentration within 72 hours of fermentation increased from $13 \mathrm{~g} / \mathrm{L}$ to $21.3 \pm 0.7 \mathrm{~g} / \mathrm{L}$ when added with glycerol $2 \%(\mathrm{w} / \mathrm{v})$. The optimal removal efficiency of $\mathrm{Ni}$ from (primary treated) wastewater was found at $80 \%$ when using 35 $\mathrm{mg} / \mathrm{L}$ of EPS extracted by centrifugation method. Wang, et al. [16] studied about the removal of $\mathrm{Pb}$ (II) and $\mathrm{Zn}$ (II) from aqueous solution via biosorption using EPS of Rhizobium radiobacter. They found that the optimum $\mathrm{pH}$ for biosorption process included $\mathrm{pH} 5$ for $\mathrm{Pb}$ (II) removal and $\mathrm{pH} 6$ for $\mathrm{Zn}$ (II) removal, respectively. The kinetic analysis results showed that the biosorption followed pseudo $1^{\text {st }}$ order and Langmuir model. The adsorbed heavy metals could be desorbed effectively using $\mathrm{HCl}$. The desorbed EPS could still reach $80 \%$ of initial biosorption capacity after being reused five times. These results showed that EPS had potential application for removal $\mathrm{Pb}$ (II) and $\mathrm{Zn}$ (II).

Additionally, there have also been several literatures that particularly reported about the use of EPS for the removal Chromium. Long, et al. [4] reported the use of EPS produced from Pseudochrobactrum saccharolyticum for the reduction of $\mathrm{Cr}(\mathrm{IV})$. They reported that the optimum reduction of Cr(IV) by using EPS was about $81.5 \%$. Chug, et al. [17] studied about the effect of growth phase, temperature, and $\mathrm{pH}$ on the production of EPS by Azotobacter beijreinckii and Bacillus subtilis and their performances to remove $\mathrm{Cr}(\mathrm{IV})$ from aqueous solution. The test results found that using Azotobacter beijreinckii could produce optimum EPS after 24 hours at $30^{\circ} \mathrm{C}$ and $\mathrm{pH} 7$, while Bacillus subtilis could produce optimum EPS after 96 hours at $37{ }^{\circ} \mathrm{C}$ and $\mathrm{pH} 7$. Furthermore, from the biosorption tests, they revealed that from initial $\mathrm{Cr}(\mathrm{IV})$ concentration of $10 \mathrm{ppm}$, the optimum reduction of $\mathrm{Cr}(\mathrm{IV})$ by using EPS were $26 \%$ and $48 \%$ for EPS produced by Azotobacter beijreinckii and Bacillus subtilis, respectively. There have been many other literatures that studied the utilization of EPS for removing chromium from aqueous solution [11,17-19].

It is well known that activated sludge is one of the most widely used processes in treating wastewater. This method has disadvantage of great amount production of activated sludge waste, which is also considered as pollution. To decrease such pollution, it needs to reduce the volume and mass of activated sludge. The activated sludge taken from wastewater treatment contains millions of bacterial colonies. Based on the literatures, EPS can be extracted from activated sludge [9, 15, 20]. Hence, the use of EPS has two purposes or advantages: to remove heavy metals and to utilize activated sludge, which may reduce the mass and volume of the sludge [9].

The EPS can be extracted from activated sludge using centrifugation or solvent extraction method. The EPS can be directly dispersed or immobilized on the polymer matrix as solid biosorbent, which can be applied in column operation process. The immobilized EPS on the polymer matrix has more advantages than the dispersion operation. For instance, the immobilized EPS can be employed in the packed-tower or fluidized-bed reactor. Here, the higher the loading capacity of biomass on the column, the easier the regeneration of saturated biomass [21].

Epoxy resin is the mixture of the monomers of bisphenol A and epichlorohydin having the chemical formula as shown in Figure 1.Epoxy resin has good mechanical properties and 
chemical resistance. The hardener of resin functions as the catalytic of polymerization reaction between the monomers. Additionally, epoxy resin has a sorption capability for chromium ions [22].

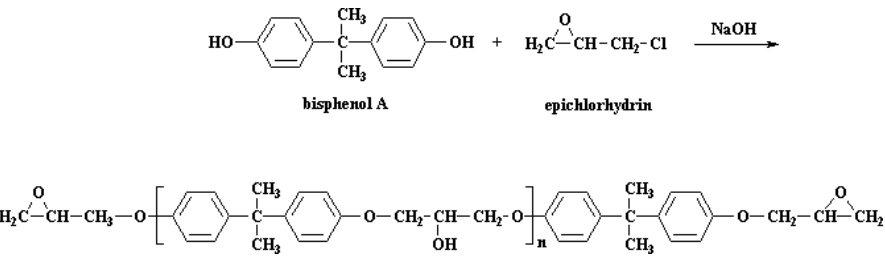

Fig 1. Chemical structure of bisphenol A, epichlorhydrin and epoxy resin

The relation between mass ratio of resin and hardener to epoxy polymer qualities has been studied in our previous work [23], as shown in Table 1 in which the weight ratio of resin and hardener that gave the best quality of epoxy was the ratio of 1:1, giving the compressive strength of epoxy of 37.5 $\mathrm{kN} / \mathrm{Cm}^{2}$

Table 1. Relation between mass ratio of resin and hardener to epoxy polymer quality [23]

\begin{tabular}{|c|c|c|c|c|}
\hline \multicolumn{2}{|c|}{ Weight ratio \% } & \multirow{2}{*}{$\begin{array}{c}\text { Resin } \\
\text { ratio/ } \\
\text { Hardener }\end{array}$} & \multicolumn{2}{|c|}{ Quality of polymerization result } \\
\hline Resin & Hardener & & $\begin{array}{l}\text { Density } \\
\left(\mathrm{gr} / \mathrm{cm}^{3}\right)\end{array}$ & $\begin{array}{c}\text { Compressive } \\
\text { strength }\left(\mathrm{kN} / \mathrm{cm}^{3}\right)\end{array}$ \\
\hline 25 & 75 & 0.33 & - & - \\
\hline 30 & 70 & 0.43 & 1.02 & 35 \\
\hline 40 & 60 & 0.67 & 1.04 & 36 \\
\hline 50 & 50 & 1.00 & 1.08 & 37.5 \\
\hline 60 & 40 & 1.50 & 1.08 & 36.5 \\
\hline 70 & 30 & 2.33 & 1.07 & 36.3 \\
\hline
\end{tabular}

\section{Materials and Methods}

\subsection{Material}

Materials for the experiment included industrial activated sludge, Whatman 41 filter paper big size pore, sodium hydroxide, chromium (III) nitrate nanohydrate $\left[\mathrm{Cr}\left(\mathrm{NO}_{3}\right)_{3} \cdot 9 \mathrm{H}_{2} \mathrm{O}\right]$, and potassium chromate $\left[\mathrm{K}_{2} \mathrm{CrO}_{4}\right]$.

\subsection{Equipment}

The equipment used on the experiment included $\mathrm{pH}$ meter, centrifuge, atomic absorption spectrophotometer (AAS), and Fourier Transform Infra Red (FTIR) Spectroscopy.

\subsection{Method}

\subsubsection{Preparation of Artificial Liquid Waste}

The artificial liquid waste was prepared similar to tannery industrial waste containing total chromium of $15.9 \mathrm{ppm}$ (trivalent of chromium $15.2 \mathrm{ppm}$ and hexavalent of chromium $0.7 \mathrm{ppm})$. It has been done by dissolving $0.1368 \mathrm{~g}$ of chromium nitrate nanohydrate and $0.003 \mathrm{~g}$ of potassium chromate on 1 liter of water.

\subsubsection{Extraction of EPS from Activated Sludge}

Activated sludge from tannery industrial wastewater treatment was filtered using filter paper with big pore size. Afterward, the cake was washed using distilled water for cleaning its impurities. The clean cake was suspended using distilled water with 5 times volume of the cake. The suspension was then heated at $80{ }^{\circ} \mathrm{C}$ for 10 minutes and then cooled down until reaching the ambient temperature. The suspension was then centrifuged at $6,000 \mathrm{rpm}$ and $4{ }^{\circ} \mathrm{C}$ for 20 minutes. Afterward, the resulted water supernatant was filtered to clean the remaining impurities and the filtered supernatant was the EPS. The EPS solution was then stored in the refrigerator. The EPS was also analyzed to evaluate the contents of protein, polysaccharides, and lipid. The solution of EPS was then extracted again by adding ethanol $96 \%$ in the solution until the ethanol concentration achieving $70 \%$ on the temperature of $4{ }^{\circ} \mathrm{C}$. The EPS precipitate was then separated using centrifuge at $5000 \mathrm{rpm}$ for 15 minutes. After precipitation process, the EPS was analyzed by FTIR (Fourier Transform Infra-Red) to determine the presence of functional groups such as hydroxyl, carboxyl, and amino carboxylic.

\subsubsection{Formation of Epoxy Polymer}

The epoxy polymer was prepared by mixing the epoxy resin of $1700 \mathrm{mg}$ with hardener on its ratio of $1: 1$. Its homogeneous mixture was molded. The dry mixture was then crushed using rocklabs and sieved using a sieve shaker to obtain the particle size of 30-40 mesh.

\subsubsection{Formation of Immobilized EPS Epoxy Polymer Biosorbent}

The result of EPS from the extraction of activated sludge on the quantity $300 \mathrm{mg}$ was mixed with $1700 \mathrm{mg}$ of epoxy resin and hardener having ratio of $1: 1$. Its homogenous mixture was molded. The dry mixture was then crushed using rocklabs and sieved using a sieve shaker to obtain the particle size of 30-40 mesh.

\subsubsection{Chromium Sorption Capability of Epoxy Resin}

The epoxy polymer of $1700 \mathrm{mg}$ with a particle size of 30-40 mesh was submerged and mixed with the prepared artificial liquid waste containing 15.9 ppm of chromium for 5 hours. After the solution was homogenized, it was analyzed to determine its chromium content by using Atomic Absorption Spectrophotometer (AAS)

\subsubsection{Chromium Sorption Capability of Immobilized EPS- Epoxy Resin Biosorbent}

The immobilized EPS - epoxy polymer biosorbent of 2000 mg with a particle size of 30-40 mesh was mixed homogeneously in the prepared artificial liquid waste containing 15.9 ppm of chromium on $\mathrm{pH} 5$ for 5 hours. After the test, the solution was analyzed to determine its chromium content by using AAS. This procedure was repeated for $\mathrm{pH}$ solution of 6 and 7 . 


\section{Results and Discussion}

The solution of EPS extracted from activated sludge had the dry weight of $2.96 \mathrm{~g} / \mathrm{L}$, so the weight of $300 \mathrm{mg}$ was equivalent to EPS solution volume of $101.35 \mathrm{~mL}$. To ensure that the resulted water supernatant from the extraction of activated sludge was the EPS, it was necessary to determine the contents of polysaccharides (carbohydrate), protein and lipids (fat) on the EPS. The analysis result of the contents of carbohydrate, protein and fat were $60 \%, 77 \%$ and $11 \%$ respectively, as shown in Table 2 .

Table 2. Analysis Result of EPS Composition

\begin{tabular}{lccc}
\hline $\begin{array}{l}\text { Analyzed } \\
\text { Component }\end{array}$ & $\begin{array}{c}\text { Analysis } \\
\text { Result }(\%)\end{array}$ & $\begin{array}{c}\text { Reference EPS } \\
\text { percentage [9] (\%) }\end{array}$ & $\begin{array}{c}\text { Analysis } \\
\text { Method }\end{array}$ \\
\hline Polysaccharides & 60 & $40-95$ & Gravimetri \\
\hline Protein & 77 & $1-60$ & Luff school \\
\hline Lipid & 11 & $1-10$ & Kjeldahl \\
\hline
\end{tabular}

The example of polysaccharides are chitin, cellulose, starch, carbohydrate, and glycogen. If the polysaccharides content is assumed 5 times of the carbohydrate content (i.e. $12 \%$ ), so the percent of polysaccharide is $60 \%$ of total EPS, which is according to the reference value (i.e. $40-95 \%$ ). The protein percentage in the EPS is $77 \%$, which is according to the reference value (i.e. 1-60\%). The lipid percentage in the EPS is $11 \%$, which is according to the reference value (i.e. 1$10 \%$. Overall, the values are in accordance with the reference of the EPS in activated sludge.

The analysis result of EPS functional group by FTIR Spectroscopy is presented in Fig. 2. As seen in Fig. 2, the prepared EPS contained the chemical bound of $\mathrm{CH}$ on medium-strong intensities of $1300-1500 \mathrm{~cm}^{-1}$, and weak intensities of $600-900 \mathrm{~cm}^{-1}, \mathrm{OH}$ on medium-strong intensities of 1200- $1500 \mathrm{~cm}^{-1}$, NH on medium-strong intensities of $1500-1700 \mathrm{~cm}-1$, and medium intensities of $700-900 \mathrm{~cm}^{-1}$ and $\mathrm{C}=\mathrm{O}$ on the medium intensities of 1600 $1900 \mathrm{~cm}^{-1}$.According to the existing bound, it could be indicated that the EPS contained functional groups of carboxyl, hydroxyl and amino carboxylic. This indicated that the EPS could act as the cation and anion exchanger for the removal of chromium waste.

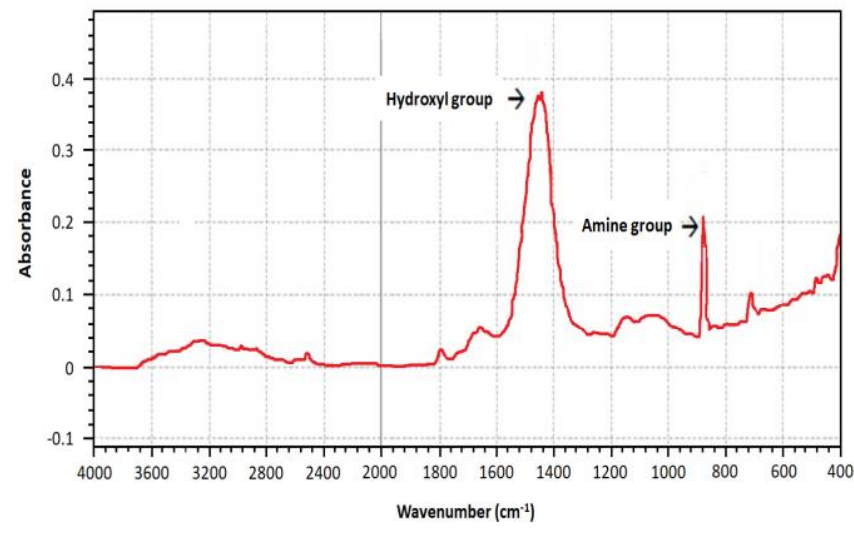

Fig 2. The analysis result of EPS by spectroscopy of FTIR

Based on the literatures review, epoxy resin and EPS have the capability of Chromium sorption. As shown in Fig. 1, epoxy resin had the hydroxyl functional group. The solution waste contained the anion of $\mathrm{Cr}_{2} \mathrm{O}_{7}^{-2}$ being another form of anion $\mathrm{CrO}_{4}^{-2}$ on the acid condition. According to Equation (8), the anion $\mathrm{Cr}_{2} \mathrm{O}_{7}^{-2}$ had the greater selectivity than the anion $\mathrm{OH}^{-}$, so the anion $\mathrm{OH}^{-}$was driven out and replaced by the anion $\mathrm{Cr}_{2} \mathrm{O}_{7}{ }^{-2}$, which resulted in the decrease of chromium concentration on the solution from $15.9 \mathrm{mg} / \mathrm{L}$ to $14.5 \mathrm{mg} / \mathrm{L}$. There was amount of chromium trapped on the molecule of epoxy resin.

Table 3 presents the data of chromium sorption capabilities of biosorbent. Based on Table 3, it was found that different values of $\mathrm{pH}$ gave the different values of chromium sorption capability of the biosorbent. The $\mathrm{pH} 5$ gave the best result for chromium sorption capabilities of biosorbent, on the $\mathrm{pH} 5$, there was the excess of ion $\mathrm{H}^{+}$on the solution.

Table 3. Data of Chromium Sorption Capabilities of Biosorbent

\begin{tabular}{|c|c|c|c|c|c|c|}
\hline \multirow{3}{*}{$\begin{array}{c}\text { Types of } \\
\text { biosorbent }\end{array}$} & \multirow{3}{*}{$\begin{array}{c}\text { Mass of } \\
\text { Biosorbent } \\
\text { (g) }\end{array}$} & \multicolumn{4}{|c|}{ Solution } & \multirow{3}{*}{$\begin{array}{l}\text { Efficiency of } \\
\text { Elimination }\end{array}$} \\
\hline & & \multirow{2}{*}{$\mathrm{pH}$} & \multirow{2}{*}{$\begin{array}{l}\text { Vol. } \\
\text { (L) }\end{array}$} & \multicolumn{2}{|c|}{$\begin{array}{c}\text { Chromium } \\
\text { Concentration } \\
(\mathrm{mg} / \mathrm{L})\end{array}$} & \\
\hline & & & & $\begin{array}{c}\text { Initial } \\
(\mathrm{Co})\end{array}$ & $\begin{array}{l}\text { Final } \\
(\mathrm{Ce})\end{array}$ & \\
\hline $\begin{array}{l}\text { Epoxy } \\
\text { Resin }\end{array}$ & 1.70 & 2 & 1 & 15.9 & 14.5 & 8.80 \\
\hline $\begin{array}{l}\text { EPS- } \\
\text { Epoxy } \\
\text { Resin }\end{array}$ & 2.00 & 5 & 1 & 15.9 & 1.72 & 89.20 \\
\hline $\begin{array}{l}\text { EPS- } \\
\text { Epoxy } \\
\text { Resin }\end{array}$ & 2.00 & 6 & 1 & 15.9 & 7.93 & 50.11 \\
\hline $\begin{array}{l}\text { EPS- } \\
\text { Epoxy } \\
\text { Resin }\end{array}$ & 2.00 & 7 & 1 & 15.9 & 10.1 & 36.50 \\
\hline
\end{tabular}

Additionally, based on the FTIR analysis results, the biosorbent contained the functional groups of carboxyl, hydroxyl and amino carboxylic. The trivalent chromium on the presence of ion $\mathrm{H}^{+}$had the positive catalytic condition for strengthening the expulsion of ion $\mathrm{H}^{+}$on the biosorbent to be replaced by the trivalent chromium. At $\mathrm{pH} 5$, the remaining concentration of chromium had the smallest value of 1.718 $\mathrm{mg} / \mathrm{L}$. In other words, this condition resulted in the biggest efficiency of chromium elimination of $89.20 \%$.

\section{Conclusion}

The EPS extracted from activated sludge of industrial waste treatment contained polyssacharides $60 \%$, protein $77 \%$ and lipids $11 \%$. Based on the FTIR analysis results, it was noted that the EPS contained the functional groups of carboxyl, hydroxyl, and amino carboxylic. Hence, the EPS could act as cation and anion exchanger. Additionally, the EPS was immobilized on the epoxy polymer matrix to act as double ion exchangers for removing chromium from the liquid waste. The epoxy resin had the capability of chromium sorption due to its content of hydroxyl. The selectivity ion of $\mathrm{Cr}_{2} \mathrm{O}_{7}{ }^{-2}$ was greater than selectivity of ion $\mathrm{OH}^{-}$, so the ion $\mathrm{OH}^{-}$on the epoxy resin was driven out and replaced by ion $\mathrm{Cr}_{2} \mathrm{O}_{7}{ }^{-2}$, which resulted in the decrease of chromium concentration on the solution from $15.9 \mathrm{mg} / \mathrm{L}$ to be $14.5 \mathrm{mg} / \mathrm{L}$. The $\mathrm{pH}$ of the solution affected the chromium sorption capability of EPS immobilized in epoxy resin biosorbent. The $\mathrm{pH} 5$ gave the 
best result for chromium sorption capabilities of EPS-Epoxy Resin Biosorbent. At $\mathrm{pH} \mathrm{5,} \mathrm{the} \mathrm{remaining} \mathrm{concentration} \mathrm{of}$ chromium had the smallest value of $1.718 \mathrm{mg} / \mathrm{L}$. This means that this condition gave the highest efficiency of chromium elimination of $89.20 \%$.

\section{References}

1. S. Tunali, A. Çabuk, and T. Akar, Removal of lead and copper ions from aqueous solutions by bacterial strain isolated from soil, Chem. Eng. J. 115 (2006) 203-211.

2. M. N. U. Coral, H. Korkmaz, B. Arikan, and G. Coral, Plasmid mediated heavy metal resistances in Enterobacter spp. isolated from Sofulu landfill, in Adana, Turkey, Ann. Microbiol. 55 (2005) 175.

3. S. Özdemir, E. Kilinc, A. Poli, B. Nicolaus, and K. Güven, Biosorption of $\mathrm{Cd}, \mathrm{Cu}, \mathrm{Ni}, \mathrm{Mn}$ and $\mathrm{Zn}$ from aqueous solutions by thermophilic bacteria, Geobacillus toebii sub.sp. decanicus and Geobacillus thermoleovorans sub.sp. stromboliensis: Equilibrium, kinetic and thermodynamic studies, Chem. Eng. J. 152 (2009) 195-206.

4. D. Long, M. Z. Hashmi, X. Su, and S. Pongpiachan, $C r(V I)$ reduction by an extracellular polymeric substance (EPS) produced from a strain of Pseudochrobactrum saccharolyticum, 3 Biotechnol. 9 (2019) 111.

5. M. D. G. de Luna, E. D. Flores, M. C. B. Cenia, and M.-C. Lu, Removal of copper ions from aqueous solution by adlai shell (Coix lacryma-jobi L.) adsorbents, Bioresour. Technol. 192 (2015) 841-844.

6. J. Yang et al., Competitive adsorption of heavy metals by extracellular polymeric substances extracted from Klebsiella sp. $\mathrm{Jl}$, Bioresour. Technol. 196 (2015) 533-539.

7. J. Feng et al., The adsorption behavior and mechanism investigation of $\mathrm{Pb}(\mathrm{II})$ removal by flocculation using microbial flocculant GA1, Bioresour. Technol. 148 (2013) 414-421.

8. J. Wang, Q. Li, M.-M. Li, T.-H. Chen, Y.-F. Zhou, and Z.-B. Yue, Competitive adsorption of heavy metal by extracellular polymeric substances (EPS) extracted from sulfate reducing bacteria, Bioresour. Technol. 163 (2014) 374-376.

9. Y. Tian, Behaviour of bacterial extracellular polymeric substances from activated sludge: a review, Int. J. Environ. Pollut. 32 (2008) 78-89.

10. J. Guo and J. Yu, Sorption characteristics and mechanisms of Pb (II) from aqueous solution by using bioflocculant MBFR10543, Appl. Microbiol. Biotechnol. 98 (2014) 6431-6441.

11. Z. Wang et al., Effect of hexavalent chromium on extracellular polymeric substances of granular sludge from an aerobic granular sequencing batch reactor, Chem. Eng. J. 251 (2014) 165-174.

12. S. Zainus and N. Endang, Biosorption phenomena of chromium, copper, iron and zink by dispersed bacterial extracellular polymeric substance, Int. Nuc. Info. Syst. 47 (2015) 47100094.

13. T. D. Reynolds and P. A. C. Richards, Unit operations and processes in environmental engineering, no. 628.162 R333u Ej. 1. PWS Publishing Company, 1995.

14. G. Tchobanoglus, F. Burton and H. D. Stensel, Wastewater engineering: Treatment and reuse, Am. Water Work. Assoc. J. 95 (2003) 201.

15. K. Nouha, R. S. Kumar and R. D. Tyagi, Heavy metals removal from wastewater using extracellular polymeric substances produced by Cloacibacterium normanense in wastewater sludge supplemented with crude glycerol and study of extracellular polymeric substances extraction by different methods, Bioresour. Technol. 212 (2016) 120-129.

16. L. Wang, J. Yang, Z. Chen, X. Liu, and F. Ma, Biosorption of Pb (II) and Zn (II) by extracellular polymeric substance (Eps) of Rhizobium Radiobacter: equilibrium, kinetics and reuse studies, Arch. Environ. Prot. 39 (2013) 129-140.

17. R. Chug, V. S. Gour, S. Mathur, and S. L. Kothari, Optimization of extracellular polymeric substances production using Azotobacter beijreinckii and Bacillus subtilis and its application in chromium (VI) removal, Bioresour. Technol. 214 (2016) 604-608.

18. R. Jin, Y. Liu, G. Liu, T. Tian, S. Qiao, and J. Zhou, Characterization of product and potential mechanism of $\mathrm{Cr}(\mathrm{VI})$ reduction by anaerobic activated sludge in a sequencing batch reactor, Sci. Rep. 7 (2017) 1681.

19. R. Dobrowolski, A. Szcześ, M. Czemierska, and A. Jarosz-Wikołazka, Studies of cadmium(II), lead(II), nickel(II), cobalt(II) and chromium(VI) sorption on extracellular polymeric substances produced by Rhodococcus opacus and Rhodococcus rhodochrous, Bioresour. Technol. 225 (2017) 113.

20. G. Guibaud, S. Comte, F. Bordas, S. Dupuy, and M. Baudu, Comparison of the complexation potential of extracellular polymeric substances (EPS), extracted from activated sludges and produced by pure bacteria strains, for cadmium, lead and nickel, Chemosphere 59 (2005) 629-638.

21. S. Zainus and A. A. Pungky, Utilization potency of extracellular polymeric substance as industrials biosorbent and ion exchange resin, Chem. Mat. Eng. 12 (2012) 1-8.

22. E. E. Ergozhin, G. K. Kabulova, A. I. Nikitina, and N. A. Bektenov, Sorption capacity of new cation exchangers based on oil residue and epoxy resin for chromium(III) ions, Russ. J. Appl. Chem. 81 (2008) 1356-1359.

23. Z. Salimin and Wati, Solidification of sludge resulting from biooxidation process of organic waste of phosphate acid purification using epoxy matrix, Proceeding of Scientific Presentation and Meeting, Yogyakarta, June 2008. 